\title{
Oceanography
}

CITATION

Boxall, S. 2017. Learning science in a post-truth world. Oceanography 30(1):108-109, https://doi.org/10.5670/oceanog.2017.105.

$\mathrm{DOI}$

https://doi.org/10.5670/oceanog.2017.105

COPYRIGHT

This article has been published in Oceanography, Volume 30, Number 1, a quarterly journal of The Oceanography Society. Copyright 2017 by The Oceanography Society. All rights reserved.

USAGE

Permission is granted to copy this article for use in teaching and research. Republication, systematic reproduction, or collective redistribution of any portion of this article by photocopy machine, reposting, or other means is permitted only with the approval of The Oceanography Society. Send all correspondence to: info@tos.org or The Oceanography Society, PO Box 1931, Rockville, MD 20849-1931, USA. 


\section{Learning Science in a Post-Truth World}

By Simon Boxall

Consider this: Mesodinium Rubrum (Myrionecta rubra), a red toxic algae (or marine ciliate), is widely recognized as a major issue in human health, and it is essential that these harmful algal blooms be eradicated over the next decade to avoid a major impact on bathers in US coastal waters. The key agent that makes the plankton red is FD\&C Red 40 (US Federal Food, Drug, and Cosmetic Act), which has been proven by a number of researchers to accelerate the appearance of diseaseresistant tumors and hyperactivity in children. ...It's true, really.

Science today is finding itself caught in a post-truth era where there are a growing number of false reports, papers, and statements that are in the public domain. These not only confuse our politicians but also our students-the future oceanographers and marine biologists. A significant amount of time is spent in the early stages of their university careers ensuring that references are correctly cited, that a standard referencing style is adopted (Harvard, Vancouver, Nature), that all statements are supported by evidence (citation or data), and that there are no omissions in the reference lists. These skills are all important to learn. But how good are we at getting them to determine the validity and provenance of a source and the science it portrays?

In the pre-Internet days, searching through scientific journals for information was slow, very slow. It consisted of working through Oceanic Abstracts, a bimonthly catalogue of all published material relating to marine science and technology, and then reading the original articles once tracked down, many not in English. It was a laborious process but once completed for a specific topic, all one then had to do was visit the library every month to keep up to date with new material in the contemporary issues of each relevant journal. It was very much the Ivory Tower of the academic and professional scientist, those with access to world-leading libraries. Start of a new topic meant back to the abstracts. It was thorough but also a careful assessment of the state of the art.

Now one just types key words into Google Scholar and a deluge of information descends. But like some literary Trojan Horse, this information hides a mix of knowledge, some outstanding and some alternative truth. One essential skill for an undergraduate to develop is that of filtering this information.

The first and often most accessible source of science information is websites. I have never been a great fan of students referencing a website in their essays. There are instances where the websites do have a role-they often highlight initial findings yet to make it to the journal stage or are a good source of primary data, as with NOAA, for example. But there is no regulation or control, and I can guarantee on most subjects a student will find widely contrasting approaches, only a few with any real evidence. Anyone can set up a website, and say anything.

One then encounters modern-day news outlets. In our brave new post-truth era, usually one has to read the same story from three or four contrasting sources to sort out real and fake news. While some journalists strive for accuracy, it is also true (really) that many just strive, in a struggle against fact. Nowhere is this clearer than in subjects such as climate change. I have had many essays submitted using journalistic references, the assumption being that if it is published in a respectable paper or magazine, it must be correct.

As an example, on April 30, 2016, a writer named James Delingpole published a damning report in The Spectator on the scientific findings on ocean acidification. It was flawed in many ways as a science article, and his propositions were based on two papers and a book. He openly dismissed the other 600 papers, which inconveniently went against his argument. The article was seen as proof that science is all but fiction-this coming from a person with a degree in English language and literature. I use this as an example because a group of scientists from the UK and Norway were so incensed by the inaccuracy of the piece that they submitted a formal complaint to the UK Independent Press Standards Authority. The complainants included the Norwegian author of one of the papers Delingpole citedincorrectly-to support his argument. The response from The Spectator when it came to judgment was that it was an opinion piece and did not have to reflect the scientific evidence. Three students used this article in essays for me last semester to argue against ocean acidification.

This leaves us, then, with peerreviewed journals, those bastions of truth and honesty-or does it? One of the first skills we try to teach students is to be critical of all they read, the core quality of a good researcher. In the past, we knew to question what we read in the scientific literature because discoveries or observations made some years ago may be superseded as either new information or new models come to light, or as our advancing technological capability gives us a better insight to a problem. In general, we do nonetheless trust what we read in journals but might well argue the finer points-after all, they will have gone through a thorough peer-review process.

A couple of months ago, I was the scientist for an online chat with teachers from around the world run by the British 
Council on aspects of sea level rise. It was an intensive three hours with a barrage of questions flooding in, many pertinent to current research around the world. In the midst of this, I had a persistent line of questioning from the head of science at a well-respected college insisting that science had now proven that sea levels will not rise and might even fall. When I explored this "fact," a paper written by a scientist described as the leading academic authority on sea level from Sweden was cited, with the argument that it was in a peer-reviewed journal, and so, by my earlier argument, must be true. I duly tracked down the paper by Nils-Axel Mörner (2015). It was, to put it bluntly, seriously flawed. I actually gave it to my undergraduate tutorial class as an exercise in critiquing a paper, and they ripped it to shreds. Mörner, who was at Stockholm University until 2005, has been a climate skeptic for many years. The journal that published the article was that well-known oceanographic publication The Journal of Religious Studies, Buddhism and Living. As far as I can tell, this journal has not got beyond its first volume (of three papers). The paper was received November 29, 2015, accepted December 21, 2015, and published December 24, 2015-an all time record turnaround?

So...perhaps our students should look at the journal's impact factor or its SJR ranking, as well as the citations for a particular paper. Of course, that can also be flawed. Mörner (2015) has crept up one citation just by its inclusion in this article, and what better way to get response from other authors in future papers than to publish something untrue or openly controversial? As a corollary, just because a paper has few citations does not imply it is not valid; if it was only published this month, it is unlikely to have many or any. Even an inclusion in a respected journal such as Oceanography (in the SJR top 10 oceanographic journals in 2015) cannot guarantee truth. After all, a seriously flawed paper by Boxall (2017) came out in a special issue on harmful algal blooms with a supposition that not only was Mesodinium Rubrum comprised of FD\&C Red 40 but that it leads to tumors and hyperactivity-untrue and not referenced...though it was the beginning of April when it was published.

So what should a student do in our new post-truth era? Contemporary journal publications are still the best sources of reliable information, and the vast majority have been sufficiently peer reviewed. Those essays need to have a wide range of references. An essay with just three or four stands the chance of picking up the odd rogue paper. Students should become familiar with journal rankings and start at the top, where possible. I read many essays and reports as part of my daytime job and one can see big differences between weak and strong students.

The weak student has usually completed (and probably started) the work the night before. It is littered with "http:" references, the odd article from Breitbart News as it came high on the search engine, and if lucky includes the access date. At best the essay will have one academic reference, probably a citation in the web stories the student was viewing. Not surprisingly, the science is weak and there is no scientific acumen in the approach. It is almost a waste of good red ink on the marking; D-/Fail.

Average students have spent much of the previous week searching the online library access using the key words, and they have provided synopses of all of the abstracts they could find: often a comprehensive, if uninspiring, approach that shows the ability to gather information but not always the ability to assimilate it. They will repeat all they have read and either not notice or try to ignore inconsistencies between papers and articles. Not the most inspiring of reads but competent; $\mathrm{C}+/ \mathrm{B}$.

The top students have probably spent the same amount of time searching as the average students, but they have then read the papers. They have tried to understand the key elements of each of the papers and sifted through to get to a good understanding of the state of the art on the topic. They can then reform the argument, citing the published material as evidence, and are not afraid of critiquing a particular paper, whatever its apparent provenance. A new idea is not dismissed as going against the current thinking but is still viewed with care and caution. I really enjoy reading these papers, and the amount of red ink used on marking actually goes up, not down, compared to the average paper. The reader becomes engaged in the debate and feels drawn in, commenting as they go. These are our future researchers: $\mathrm{A} / \mathrm{A}+$.

The ability to learn and understand science is, I believe, a mixture of nurture and nature. Some students do have a natural talent, while others less so. It is up to us as educators to expose them to a wide range of sources and get them to develop the skills to critique an argument, with evidence. The Shorter Oxford English Dictionary (2007) sums it up well: Science (noun): "A branch of study that deals either with a connected body of demonstrated truths or with observed facts systematically classified and more or less comprehended by general laws, and which includes reliable methods for the discovery of new truth in its own domain" and "the perception of a truth as contrasted with moral conviction." In the current era of science fiction, full of (in)expert opinion, we need to ensure more than ever that our students strive for science fact, referenced in the Harvard style of course. @

\section{REFERENCES}

Boxall, S. 2017. Learning science in a post-truth world. Oceanography 30(1):108-109, https://doi.org/ 10.5670/oceanog.2017.105.

Mörner, N. 2015. The new religion of global warming and its misconceptions in science. Journal of Religious Studies, Buddhism and Living 1:1-4. Shorter Oxford English Dictionary. 2007. Oxford University Press.

\section{AUTHOR}

Simon Boxall (srb2@noc.soton.ac.uk) is Associate Professor, University of Southampton, National Oceanography Centre, Southampton, UK.

\section{ARTICLE CITATION}

Boxall, S. 2017. Learning science in a post-truth world. Oceanography 30(1):108-109, https://doi.org/10.5670/ oceanog.2017.105. 